\title{
Analysis of gliadin patterns and diversity in Triticum polonicum L. acces- sions from Ethiopia
}

\author{
Eleni SHIFERAW ${ }^{1,2}$
}

Received October 19, 2020; accepted January 24, 2021.

Delo je prispelo 19. oktobra 2020, sprejeto 24. januarja 2021.

\begin{abstract}
Analysis of gliadin patterns and diversity in Triticum polonicum L. accessions from Ethiopia

Abstract: Gliadins from 25 accessions represented by 350 individual seed samples were analysed by acid-polyacrylamide gel electrophoresis (A-PAGE) with the objective of identifying gliadin band patterns and examine the extent of diversity in Triticum polonicum L. collections from Ethiopia. Seventy polymorphic bands and 68 different patterns were identified. Eighteen different mobility bands and 16 patterns were identified in $\omega$-gliadin region, 22 bands and 20 patterns in $\gamma$-gliadin region, 12 bands and 22 patterns in $\beta$-gliadin region and 18 bands and 10 patterns in $\alpha$-gliadin region. The average genetic diversity calculated from the data of the four gliadin zones of the analysed samples was 0.15 . The $\gamma$ region have the highest diversity $(H=0.193)$, followed by $\omega$ regions $(H=0.177)$ and $\beta$ region $(\mathrm{H}=0.168)$ and the lowest diversity was observed in $\alpha$ region $(\mathrm{H}=0.127)$. Cluster analysis based on genetic distances resulted in grouping of the analysed accessions in to seven main groups. Though the level of diversity was relatively lower than other tetraploid wheat species from Ethiopia, the findings are indicative of the existence of variation in the collections which can be exploited for wheat improvement.
\end{abstract}

Key words: A-PAGE; genetic diversity; gliadin; Triticum polonicum
Analiza vzorcev gliadinov in raznolikosti akcesij poljske pšenice (Triticum polonicum L.) v Etiopiji

Izvleček: V raziskavi so bili s kislo poliakrilamidno gelsko elektroforezo (A-PAGE) analizirani gliadini 25 akcesij poljske pšenice v 350 vzorcih semen $\mathrm{z}$ namenom določiti vzorce gliadinskih prog in ugotoviti obseg raznolikosti te pšenice v Etiopiji. Določeno je bilo 70 polimorfnih prog in 68 različnih vzorcev. Osemnajst različnih mobilnih prog in 16 vzorcev je bilo določenih v območju $\omega$-gliadinov, 22 prog in 20 vzorcev v območju $\gamma$-gliadinov, 12 prog in 22 vzorcev v območju $\beta$-gliadinov in 18 prog in 10 vzorcev v območju $\alpha$-gliadinov. Poprečna genetska raznolikost, izračunana na osnovi podatkov analiziranih vzorcev za ta štiri območja gliadinov je bila 0,15 . Območje $\gamma$ je imelo največjo raznolikost $(H=0,193)$, sledili sta mu območji $\omega$ $(\mathrm{H}=0,177)$ in $\beta(\mathrm{H}=0,168)$, najmanjša raznolikost je bila ugotovljena v območju $\alpha(H=0,127)$. Analiza grozdov na osnovi genetske oddaljenosti je združila analizirane akcesije v sedem glavnih skupin. Čeprav je raven raznolikosti nekoliko manjša kot pri drugih tetraploidnih vrstah pšenice $\mathrm{v}$ Etiopiji, so odkritja pokazala obstoj spremenljivosti v zbirkah, ki bi jih lahko uporabili pri izboljšanju pšenice.

Ključne besede: A-PAGE; genetska raznolikost; gliadin; Triticum polonicum 


\section{INTRODUCTION}

Focus given mainly to increasing grain yield and crop productivity has resulted in an increase in micronutrient deficiency in food grains (Garg et al., 2018). Agronomic and genetic biofortification are being used as a means to improve the deficiency of micronutrients in modern varieties. Exploitation of underutilized species is one option to meet the demand for enhanced nutrition requirements. Evaluation of minor wheat species may provide breeders with important sources of genes suitable for biotic and abiotic stress tolerance and nutrition improvement. Among the many underutilized crops Triticum polonicum L., commonly known as Polish wheat, offers valuable agronomical and nutritional benefits that can be incorporated in to wheat varieties currently in use. Triticum polonicum L., $2 \mathrm{n}=28$, AABB), is a species which is grown sporadically in Africa (Ethiopia and Algeria), Europe (Spain, Italy, Ukraine and Russia) and some countries in the Asia temperate (USDA, 2020). Lately, T. polonicum is gaining attention due to its desirable traits. In comparison with durum and bread wheat, it has abundant protein and ash content and low fat content (Bieńkowska et al., 2019a) and it has good content of iron phosphorus, zinc, sulphur, magnesium, and boron, in addition to a lower content of aluminum (Bieńkowska et al., 2019b). Starch with up to $43.2 \%$ amylase content was also reported in the grain of T. polonicum (RodriguezQuijano et al., 2003). Foods with high amylase content take longer to digest hence to improve diet, cereals with high amylase content are needed (Vaziri et al., 2014). It is also shown to have potential and useful attributes in durum wheat breeding for drought tolerance (Hakimi et al., 1998).

Since most of the new varieties of wheat are notably poorer in mineral content breeders have specified $T$. polonicum as a genetic resource with good potential to enhance wheat's nutrition, specifically for genetic biofortification of durum and bread wheat (Bieńkowska et al., 2019b). The species is also reported to show satisfactory resistance to Fusarium head blight (Wiwart, 2013), and could be a potential source of semi-dwarfing genes for the development of durum wheat cultivars (Watanabe, 2004). T. polonicum can be used in wheat breeding programs since it can be crossed and produce fertile and genetically stable hybrids with $T$. aestivum L. and T. $d u$ rum Desf. (Akond et al., 2006; Hakimi et al., 1997).

Gliadins are mainly monomeric proteins that are not affected by environment (Lookhart \& Finney, 1984) and coast effective hence they make good tool for identifying genetic differences and determine quality (Bushuk \& Zillman, 1978; Payne, 1987). In prior studies high and low molecular weight glutenin subunits composition of
Ethiopian tetraploid wheat (Hailu et al., 2006) and allelic variation of gliadin coding loci of improved durum wheat varieties from Ethiopia (Hailegiorgis et al., 2017) have been reported. T. polonicum is one of the minor tetraploid wheat species cultivated in Ethiopia with limited importance, usually grown mixed with T. durum and T. aestivum (Demissie \& Habtemariam, 1991) with earlier reports of cultivation in pure stands as well (Engels \& Hawkes, 1991). It is a neglected crop in terms of conservation, research and utilization. The diversity of gliadin patterns in Ethiopian tetraploid wheat has not been reported so far. Genetic diversity study in conserved genetic resources of the species is important to better utilize and manage the resource. This study examined gliadin pattern and diversity of some T. polonicum collections from Ethiopia.

\section{MATERIALS AND METHODS}

\subsection{PLANT MATERIAL AND GLIADIN EXTRAC- TION}

Twenty five T. polonicum accessions from Ethiopia obtained from the Ethiopian Biodiversity Institute were used for this study. Fourteen seeds from each accession (a total of 350 individual seed samples) were used for gliadin profiling and diversity assessment. Each wheat grain was crushed using mortar and pestle and gliadin was extracted with $70 \%(\mathrm{v} / \mathrm{v})$ ethanol allowing the mixture to stand at $40{ }^{\circ} \mathrm{C}$ for 45 minutes and at $+4{ }^{\circ} \mathrm{C}$ until electrophoresis. Aliquot of the supernatant was mixed with sample buffer (18\% sucrose containing methyl green tracking dye) before loading $25 \mu \mathrm{l}$ of the extract on the gel.

\subsection{A-PAGE}

Glidins were fractionated using acid -polyacrylamide gel electrophoresis (A-PAGE), containing acrylamide $(7.5 \%)$ and bis-acrylamide $(0.375 \%)$ with ferrous sulfate $(0.009 \%)$ and ascorbic acid $(0.00018 \%)$ polymerized by the addition of hydrogen peroxide (15\%). Electrophoresis was performed at $50 \mathrm{~V}, 150 \mathrm{~V}$ and $250 \mathrm{~V}$ for $10 \mathrm{~min}$ each, at $350 \mathrm{~V}$ for $60 \mathrm{~min}$ and at $550 \mathrm{~V}$ for 80 minutes in $0.05 \mathrm{M}$ aluminum lactate ( $\mathrm{pH}$ 3.1) buffer. The cultivar Icaro was used as a standard in each gel run to compare electrophoretic bands and patterns. At the end of the run, gels were fixed using $12 \%$ trichloroacetic acid for 15 minutes and stained overnight in staining solution containing $0.04 \%(\mathrm{w} / \mathrm{v})$ Coomassie brilliant blue R-250 in $100 \mathrm{ml}$ ethanol and $80 \mathrm{ml} 12 \%$ trichloroacetic acid. 
After destaining using tap water, gels were photographed on a white illumination source for documentation. Each sample was run twice to confirm the gliadin profile.

\subsection{DATA ANALYSIS}

Banding pattern of each individual seed was compared within and among accessions and the standard cultivar to distinguish the different gliadin bands and patterns. Each different band of individual seeds displayed by gliadin loci was scored for its presence (1) or absence (0). The data obtained were entered as a binary data matrix and used to perform genetic diversity measures using GenAlEx 6.5 (Peakall \& Smouse, 2012). Gene diversity was computed as the expected heterozygosity $(\mathrm{H})$ based on band frequencies of gliadins. Genetic distance matrix was used to perform cluster analysis using the unweighted pair-group method for the arithmetic average (UPGMA) (Sneath \& Soakal, 1973) clustering method by TFPGA version 1.3 (Miller, 1997).

\section{RESULTS AND DISCUSSION}

\subsection{GLIADIN ELECTROPHORETIC PATTERNS}

Twenty five different accessions of T. polonicum represented by 350 samples were analyzed by A-PAGE. Electrophoretic profile for representative accessions is shown in Fig.1. Assuming that the bands with the same relative mobility represent the same subunit, a total of 70 different bands and 68 gliadin patterns were detected. The average number of gliadin bands per accession was 24 and it ranged from 14 to 37 . These bands were grouped into patterns at each of the four gliadin zones $(\alpha, \beta, \gamma$ and $\omega$ gliadins). The patterns within each gliadin group of $\alpha, \beta$, $\gamma$ and $\omega$ were identified by comparing banding patterns of each sample with each other and the standard cultivar.

Gliadin patterns in the four gliadin regions observed in the analysed samples is depicted in Fig. 2. Based on the observed gliadin profiles, 10 different gliadin patterns and 18 different mobility bands were identified in the a-gliadin region which showed limited variation compared to the other zones. Each a-gliadin pattern showed two to five bands. The most frequent pattern was pattern 1 , observed in $84 \%$ of the analysed accessions followed by pattern 2, 3 and 5 each observed in $16 \%$ of the accessions. Twenty two different gliadin patterns were identified in the $\beta$-gliadin zone each pattern showing three to six bands. The most frequent pattern was pattern $1 \mathrm{de}$ tected in $30 \%$ of the accessions followed by pattern 20 observed in $20 \%$ of the accessions. In $\gamma$-gliadin zone, 20 different patterns having one to five bands in each pattern were detected. Pattern 1 was the most frequent one appearing in $68 \%$ of the accessions. In $\omega$-gliadin zone, 16 different patterns having three to seven bands were observed. Pattern 1 was the most frequent pattern encountered in $44 \%$ of the accessions followed by pattern 11 appearing in $20 \%$ of the accessions. The number of gliadin bands and patterns, 70 and 68 respectively, detected in the present study is higher than that of Pan et al. (2007) who reported 48 gliadin bands and 65 patterns in T. polonicum accessions from different countries. In other studies, Zaefizadeh et al. (2010) reported 66 polymorphic bands and 81 patterns in durum wheat landraces and Ojaghi \& Akhundova, (2010) reported 48 bands and 47 patterns in double haploid T. aestivum. When comparing the different gliadin regions, $a$-gliadin region showed the lowest number of band patterns which is similar to find-
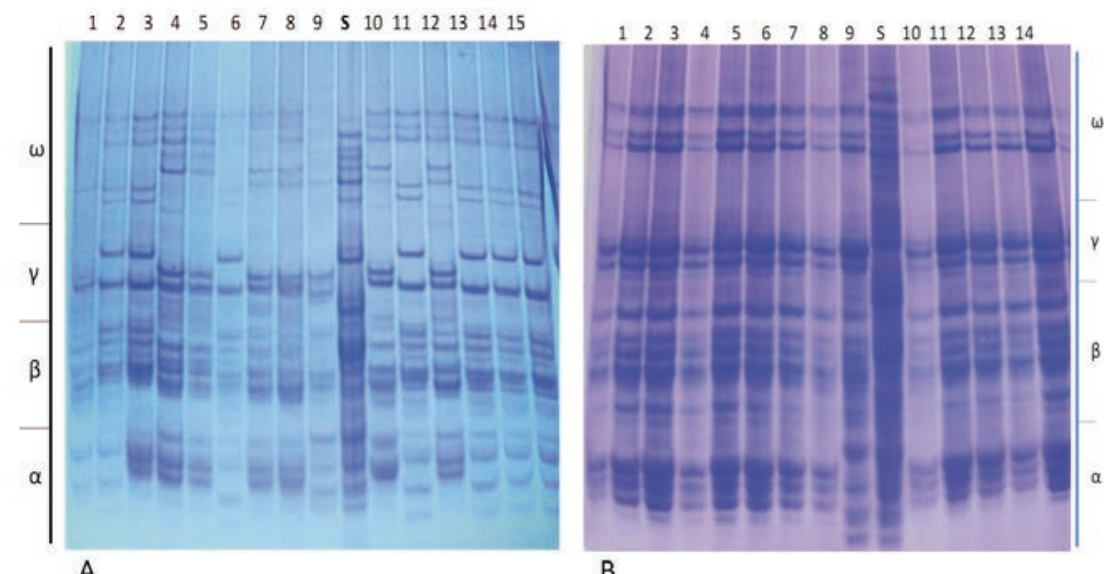

Figure 1: Gliadin electrophoretic patterns on A-PAGE for representative T. polonicum accessions showing within accession variation (A) and no variation within accession (B). 


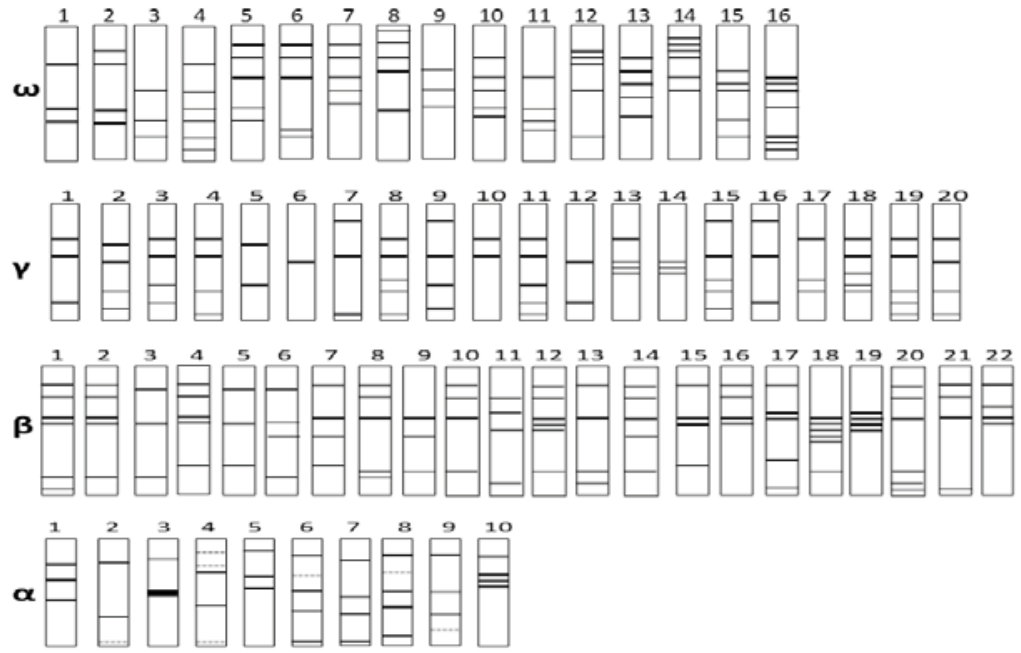

Figure 2: Electrophoregram of different gliadin patterns in $\alpha, \beta, \gamma$, and $\omega$ gliadin regions observed in the analysed samples.

ings in studies on other wheat species (Ram et al., 2005; Aliyeva et al., 2012).

\subsection{GENETIC DIVERSITY}

A total of 70 bands were scored among the studied samples. The overall frequencies of these bands ranged from 0.007 to 0.871 among all the populations. The band with the highest frequency was detected in $\gamma$ region while bands with the lowest frequency were detected in $\gamma$ and a gliadin regions. The majority of the bands $(74.28 \%)$ showed frequency of $<25 \%$. The number of bands within each accession ranged from 14 to 37 . Within accessions, the percentage of polymorphic bands ranged from 0.00 to 47.14 and the gene diversity $(\mathrm{H})$ ranged from 0.00 to 0.153 . The highest value was recorded in accession 23 (accession no. 226725) while five accessions (209774, 222726, 222632, 222242 and 226441) showed no within accession variation.

The overall gene diversity in the samples based on the patterns observed for each of the four gliadin regions showed that the $\gamma$ region has the highest diversity $(\mathrm{H}=$ $0.193)$, followed by $\omega$ regions $(H=0.177)$ and $\beta$ region $(\mathrm{H}=0.168)$ and the lowest diversity was observed in $\alpha$ region $(H=0.14)$. In all the $T$. polonicum samples (350 entries) all bands were polymorphic and the mean gene diversity estimate was 0.167 . The genetic diversity is relatively lower than other tetraploid wheat from Ethiopia examined using seed storage protein (Hailu et al., 2006) and microsatellite markers (Teklu et al., 2006; Yifru et al., 2006). Assessment of agromorphological characteristics of T. polonicum from Ethiopia had also indicated that phenotypic variation is relatively small except for the apical tooth and awn length (Demissie \& Habtemariam, 1991). Limited cultivation of the species might have caused genetic erosion resulting in low genetic variation. Hailu et al (2006) reported $100 \%$ genetic erosion of $T$. polonicum in Tigray and Gojam regions of Ethiopia and $84.4 \%$ genetic erosion throughout the country. Yifru et al. (2006) also reported a much localized use of T. polonicum which might result in its loss. Tetraploid wheat used to occupy $60 \%$ of the total wheat area (Tessema and Belay 1991). However, because of broader adaptability and yield advantage, bread wheat has been expanding in area of production substituting traditional durum and emmer wheat (Tsegaye \& Berg, 2007). Recent reports estimate that tetraploid wheat accounts for around $40 \%$ of the total wheat production (Brasesco et al., 2019), however, detail data on production of the different tetraploid wheat species is lacking.

\subsection{ANALYSIS OF RELATIONSHIP}

Nei's genetic distance (1972) among the accessions ranged from 0.00 to 0.538 . The lowest genetic distance was observed among accessions 18, 19 and 21 (0.00) followed by accession 2 and 3 (0.0002). The highest distance was observed between accessions 22 and 24 (0.538) and accession 22 and 15 (0.529). The UPGMA clustering, based on Nei's genetic distance, for the 25 accessions revealed seven major groups (Fig. 3) containing one to 10 accessions per group. Group A comprises of accessions that showed no within accession diversity while group C contains accessions with the relatively high values of gene diversity, percentage of polymorphic bands and number of bands per accession. 


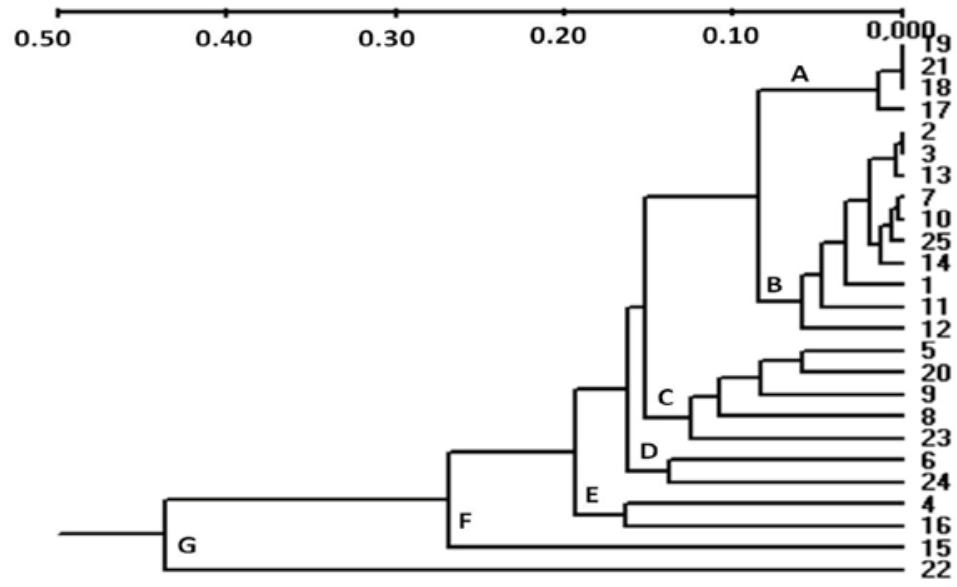

Figure 3: Dendrogram showing relationship among 25 T. polonicum accessions based on Nei's genetic distance.

\section{CONCLUSION}

Despite lower diversity revealed in the analysed accessions, the findings reported here have important implications for T. polonicum conservation and utilization in the country. In the Ethiopian genebank there are very few T. polonicum accessions. However farmers cultivate $T$. polonicum mixed with other wheat species hence wheat accessions conserved as Triticum spp also include T. polonicum as shown by activities that splits these mixed accessions in to their respective species. Splitting mixed species and additional collection of the species from potential growing areas need to be conducted so that the species can be used in improving wheat varieties in nutrient composition and disease resistance. Analysis of nutrient content and diversity analysis using molecular markers need also be carried out in order to reveal further the potential value of the species.

\section{ACKNOWLEDGEMENT}

This research was financially supported by the Ethiopian Biodiversity Institute. The author acknowledges the help of Ms Meaza Alemseged in sample preparation.

\section{REFERENCES}

Aliyeva, A., Ojaghi, J., Mehdiyeva, S. (2012). Electrophoretic profiles of gliadin subunits to evaluate genetic diversity of Azerbaijan Synthetic Branched spike wheat accessions. American-Eurasian Journal of Agriculture \& Environmental Science, 12(10), 1343-1339. https://doi:10.5829/idosi.aejaes.2012.12.10.6680.

Akond, M., Furuta, Y., Watanabe, N. (2006). Experimental introgression of the gene for long glumes through hybridiza- tion of Triticum aestivum / Triticum polonicum. Journal of genetics and breeding, 60, 141-146.

Brasesco, F., Asgedom, D., Sommacal, V., Casari, G. (2019). Strategic analysis and intervention plan for wheat and wheat products in the Agro-Commodities Procurement Zone of the pilot Integrated Agro-Industrial Park in Central-Eastern Oromia, Ethiopia. FAO, Addis Ababa.

Bieńkowska, T., Suchowilska, E., Wiwart, M. (2019a). Triticum polonicum L. as promising source material for breeding new wheat cultivars. Journal of Elementology, 25(1), 237248. http://doi:10.5601/jelem.2019.24.2.1873.

Bieńkowska, T., Suchowilska, E., Kandler, W., Krska, R., Wiwart, M. (2019b). Triticum polonicum L. as potential source material for the biofortification of wheat with essential micronutrients. Plant Genetic Resources, 17(3), 213-220. http://doi:10.1017/S1479262118000394.

Bushuk, W., \& Zillman, R.R. (1978). Wheat cultivar identification by gliadin electrophoregrams I Apparatus, method, and nomenclature. Canadian Journal of Plant Sciences, 58, 505-515. https://doi.org/10.4141/cjps78-076

Demissie, A., \& Habtemariam, G. (1991). Wheat Genetic Resources in Ethiopia. In H Gebre-Mariam, DG Tanner, and M Hulluka. (Eds.), Wheat Research in Ethiopia: A historical perspective. IAR/CIMMYT, Addis Ababa, pp 33-46.

Engels JMM, \& Hawkes JG. (1991). The Ethiopian gene centre and its genetic diversity. In J.M.M. Engeles, J.G. Hawkes, M. Worede (Eds.), Plant Genetic Resources of Ethiopia. pp 23-41. Cambridge University Press, Cambridge. https://doi. org/10.1017/CBO9780511551543.003

Garg, M., Sharma, N., Sharma, S., Kapoor, P., Kumar, A., Chunduri, V., Arora, P. (2018). Biofortified crops generated by breeding, agronomy, and transgenic approaches are improving lives of millions of people around the World. Frontiers in Nutrition, 5, 12. http://doi:10.3389/fnut.2018.00012.

Hailegiorgis, D., Lee, C.A., Yun, S.J. (2017). Allelic variation at the gliadin coding loci of improved Ethiopian Tetraploid wheat varieties. Journal of Crop Science \& Biotechnology, 20(4), 287-293. http://doi: 10.1007/s12892-017-0106-0.

Hailu, F., Johansson, E., Merker, A., Belay, G., Singh, H., Zeleke, H. (2006). Composition of and variation in high- 
and low-molecular weight glutenin subunits, and omega gliadins in Ethiopian tetraploid wheat germplasm. Plant Genetic Resources, 4(2), 134-143. https://doi.org/10.1079/ PGR2006110.

Hakimi, A., Monneveux, P., Nachit, M.M. (1997). Direct and indirect selection for drought tolerance in alien tetraploid wheat durum wheat crosses. In H.J. Braun, F. Altay, W.E. Kronstad, S.P.S. Beniwal, A. McNab (Eds.), Wheat: Prospects for Global Improvement. Proceedings of the $5^{\text {th }}$ International Wheat Conference (pp 353-360). Kluwer, London. https://doi.org/10.1007/978-94-011-4896-2_49

Lookhart, G.L., Finney, K.F. (1984). Polyacrylamide gel electrophoresis of wheat gliadins: the effect of environment and germination. Cereal Chemistry, 61, 496-499.

Miller, M.P. (1997). Tools for Populations Genetic Analyses (TFPGA) 1.3. A Windows program for the analysis of allozyme and molecular population genetic data.

Ojaghi, J. \& Akhundova, E. (2010). Genetic diversity in double haploids wheat based on morphological traits, gliadin patterns and RAPD markers. African Journal of Agricultural Research, 5(3), 1701-1712. http://doi:10.5897/AJAR09.754.

Pan, D., Hong, L., Wei, L., Peng-Fei, Q., Yu-Ming, W., Zheng, Y.L. (2007). Genetic diversity of storage proteins in Triticum polonicum. Journal of plant science, 2(4), 416-424. http://doi:10.3923/jps.2007.416.424.

Payne, P.I. (1987). Genetics of wheat storage protein and the effect of allelic variation on bread baking quality. Annual Review of Plant physiology, 38, 141-153. https://doi. org/10.1146/annurev.pp.38.060187.001041

Peakall, R., Smouse, P.E. (2012). GenAlEx 6.5: genetic analysis in Excel. Population genetic software for teaching and research-an update. Bioinformatics, 28, 2537-2539. http:// doi: 10.1093/bioinformatics/bts460.

Ram, S., Jain, N., Dawar, V., Singh, R.P., Shoran, J. (2005). Analysis of Acid-PAGE gliadin pattern of Indian wheats (Triticum aestivum L.) representing different environments and periods. Crop Science, 45, 1256-1263. https://doi. org/10.2135/cropsci2004.0334.

Rodr1'guez-Quijano, M., Lucas, R., Carrillo, J.M. (2003). Waxy proteins and amylose content in tetraploid wheats Triticum dicoccum Schulb., Triticum durum L. and Triticum polonicum L. Euphytica, 134, 97-101. http:// doi:10.1023/A:1026157713582.

Sneath, P.H., \& Sokal, R.R. (1973). Numerical taxonomy. W. H. Freeman, San Francisco.

Teklu, Y., Hammer, K., Huang, X., Roder, M.S. (2006). Analy- sis of microsatellite diversity in Ethiopian tetraploid wheat landraces. Genetic Resources and Crop Evolution, 53, 11151126. https://doi.org/10.1007/s10722-005-1146-7.

Tessema, T., \& Belay, G. (1991). Aspects of Ethiopian tetraploid wheats with emphasis on durum wheat genetics and breeding research. In H. Gebre-Mariam, D.G. Tanner, and M. Hulluka (Eds.), Wheat Research in Ethiopia: A historical perspective. (pp 47-72). IAR/CIMMYT, Addis Ababa, Ethiopia.

Tsegaye, B., \& Berg, T. (2007). Genetic erosion of Ethiopian tetraploid wheat landraces in Eastern Shewa, Central Ethiopia. Genetic Resources and Crop Evolution, 54, 715-726. https://doi.org/10.1007/s10722-006-0016-2.

USDA. (2020). Agricultural Research Service, National Plant Germplasm System. Germplasm Resources Information Network (GRIN-Taxonomy). National Germplasm Resources Laboratory, Beltsville, Maryland. Retrieved from https:// npgsweb.ars-grin.gov/gringlobal/taxonomydetail.aspx? 406898.

Vaziri, N. D., Liu, S., Lau, W.L., Khazaeli, M., Nazertehrani, S., Farzaneh, S.H., Kieffer, D.A., Adams, S.H., Martin, R.J. (2014). High Amylose resistant starch diet ameliorates oxidative stress, inflammation, and progression of chronic kidney disease. PLOS One, 9, 912. http://10.1371/journal. pone. 0114881 .

Watanabe, N. (2004). Triticum polonicum IC12196: a possible alternative source of GA3-insensitive semi-dwarfism. Cereal Research Communication, 32, 429-434. https://doi. org/10.1007/BF03543331.

Wiwart, M., Suchowilska, E., Kandler, W., Sulyok, M., Groenwald, P., Krska, R. (2013). Can Polish wheat (Triticum polonicum L.) be an interesting gene source for breeding wheat cultivars with increased resistance to Fusarium head blight? Genetic Resources and Crop Evolution, 60, 23592373. https://doi.org/10.1007/s10722-013-0004-2.

Yifru, T., Hammer, K., Huang, X.Q., Roder, M.S. (2006). Regional patterns of microsatellite diversity in Ethiopian tetraploid wheat accessions. Plant Breeding, 125, 125-130. http://10.1111/j.1439-0523.2006.01147.x.

Zaefizadeh, M., Somarin, S.J., Ojaghi, J., Seyedi, S.M., Mahmoodabad, R.Z., Ochi, M. (2010). Genetic diversity for gliadin patterns of durum wheat landraces in the Northwest of Iran and Azerbaijan. Pesquisa Agropecuária Brasileira, 45, 1425-1432. https://doi.org/10.1590/S0100204X2010001200013. 